\title{
Influence of Charge Conditions on Battery Dynamics of A Commercial Lithium-Ion Cell
}

\section{Ticari Bir Lityum-İyon Pilinin Batarya Dinamikleri Üzerinde Şarj Koşullarının Etkisi}

\section{Ugur Morali ${ }^{\odot}$}

Department of Chemical Engineering, Eskisehir Osmangazi University, Eskisehir, Turkey.

\section{ABSTRACT}

- lectrochemical impedance spectroscopy measurements were performed to determine the effect of the state-of-charge, - charge current, and current-drop time on battery dynamics of a commercial 2032 lithium-ion coin cell. The impedance response was systematically investigated and discussed by using the Taguchi design. The results showed that the state-ofcharge had a statistically significant effect on both the resistance for solid electrolyte interphase formation and cathodic charge transfer resistance. It was showed that the Taguchi design is a valuable tool for analyzing battery dynamics obtained through the equivalent circuit model. The Taguchi design opened the door for a robust design of lithium-ion batteries in real life.

\section{Key Words}

Impedance spectroscopy, lithium-ion batteries, battery dynamics, Taguchi design.

\section{öz}

Tetki icar

icari bir 2032 lityum-iyon para pilinin batarya dinamikleri üzerinde şarj durumu, şarj akımı ve akım düşüş zamanının etkilerini belirlemek üzere elektrokimyasal empedans spektroskopisi ölçümleri gerçekleştirildi. Empedans cevabı Taguchi tasarımı kullanılarak sistematik bir şekilde araştırıldı ve tartışıldı. Sonuçlar şarj durumunun katı elektrolit ara fazı oluşum direnci ve katodik şarj aktarım direnci üzerinde istatistiksel olarak anlamlı bir etkiye sahip olduğunu gösterdi. Taguchi tasarımının eşdeğer devre modeli ile elde edilen batarya dinamiklerinin analiz edilmesinde önemli bir araç olduğu gösterildi. Taguchi tasarımı gerçek yaşamda lityum-iyon bataryalarının gürbüz bir tasarımı için bir olanak sağlamıştır.

\section{Anahtar Kelimeler}

Empedans spektroskopisi, lityum-iyon bataryalar, batarya dinamikleri, Taguchi tasarımı. 


\section{INTRODUCTION}

$\Gamma$ batt here is a growing interest in the use of lithium-ion batteries (LIBS) in the fields of electronic, transportation and energy storage [1, 2]. The LIBs are assumed to have a predominant role among the various electrochemical energy storage systems. Additionally, electric vehicles with the LIBs have numerous advantageous such as better performance and zero-emission since the high energy density of the LIBS [3]. It is usually recognized that the power and energy density of LIBs depend on the electrochemical characteristics of battery components [4]. These components include anode, cathode, electrolyte, and current collectors [2]. A deep understanding of electrochemical processes in the LIBS is a critical point to optimize operation mode, safety, and cycle life to improve the reliability of the rechargeable energy storage systems. The electrochemical characteristics of LIBs can be exhibited through electrochemical impedance spectroscopy (EIS) [5]. The EIS has been demonstrated to exhibit superior characterization of battery dynamics [6]. The advantage of the EIS method is due to its non-destructive measurements, compared to other methods. The LIBs are used in the energy-required systems under different operation conditions. The parameters such as charging rate and state of charge (SOC) can influence battery performance of the LIBS. For instance, fast charging rate and high states of charge lead to the formation of Li-plating at the surface of the anode [2]. These parameters can also lead to the formation of solid electrolyte interphase (SEI) on the anode [7]. The SEI layer can be considered as a further layer between the electrolyte and the anode. In other words, these formations in the LIBs provoke the battery degradation and power fade. Therefore, the determination of the influence of both the charging current and SOC on battery dynamics is of great importance.
Recently, tremendous efforts have been made to clarify the electrochemical properties of LIBs under different process conditions [8, 9]. However, statistical evaluation of battery dynamics has not been studied in the literature. On the other hand, the identification of the significance of charging current at states of charge improves the high rate capability for charging operation. The dependence of battery dynamics on SOC and charging current is examined due to its importance in deciding the operating strategy. Accordingly, the influence of both charge current and SOC on dynamics of 2032 button cell, which has the cathode of $\mathrm{LiNiMnO}_{2}$ and the anode of graphitic carbon, has been quantified by using EIS method combined with the Taguchi design.

\section{MATERIALS and METHODS}

Commercially available and rechargeable 2032 button lithium-ion (Li-ion) cells were purchased from Sony Energy Devices Corp. The 2032 notation shows that the cell was $20 \mathrm{~mm}$ in diameter and $3.2 \mathrm{~mm}$ in height. The cathode was a lithium metal oxide such as $\mathrm{LiNiMnCoO}_{2}$, and the anode was graphitic carbon. First the open circuit potential (OCP) was measured over 120 seconds with a sample period of 0.5 seconds. The cells as received had an OCP of $3.715 \pm 0,001 \mathrm{~V}$. Then, the cells were charged at a current of $200 \mathrm{~mA}$ to $4.20 \mathrm{~V}$. The discharge profile of the cells was obtained at a current of $177 \mathrm{~mA}$ down to and including $3.20 \mathrm{~V}$. The resulting discharge profile was used to obtain a correlation between cell potential and state-of-charge. Charge-discharge measurements and EIS analyses were performed by using Gamry Reference 3000 Potentiostat/Galvonastat/ZRA. Gamry Instruments coin cell battery holder was used to protect the electrochemical measurements from the noises of cable connections. Gamry Faraday cage was also used to provide prevention due to the outer

Table 1. Experimental runs based on the L9 orthogonal array

\begin{tabular}{|c|c|c|c|}
\hline Run & SOC, $\%$ & Charge current, mA & Current drop time, second \\
\hline 1 & 35 & 30 & 30 \\
\hline 2 & 35 & 15 & 20 \\
\hline 3 & 35 & 5 & 10 \\
\hline 4 & 70 & 30 & 20 \\
\hline 5 & 70 & 15 & 10 \\
\hline 6 & 70 & 5 & 30 \\
\hline 7 & 100 & 30 & 10 \\
\hline 8 & 100 & 15 & 30 \\
\hline 9 & 100 & 5 & 20 \\
\hline
\end{tabular}




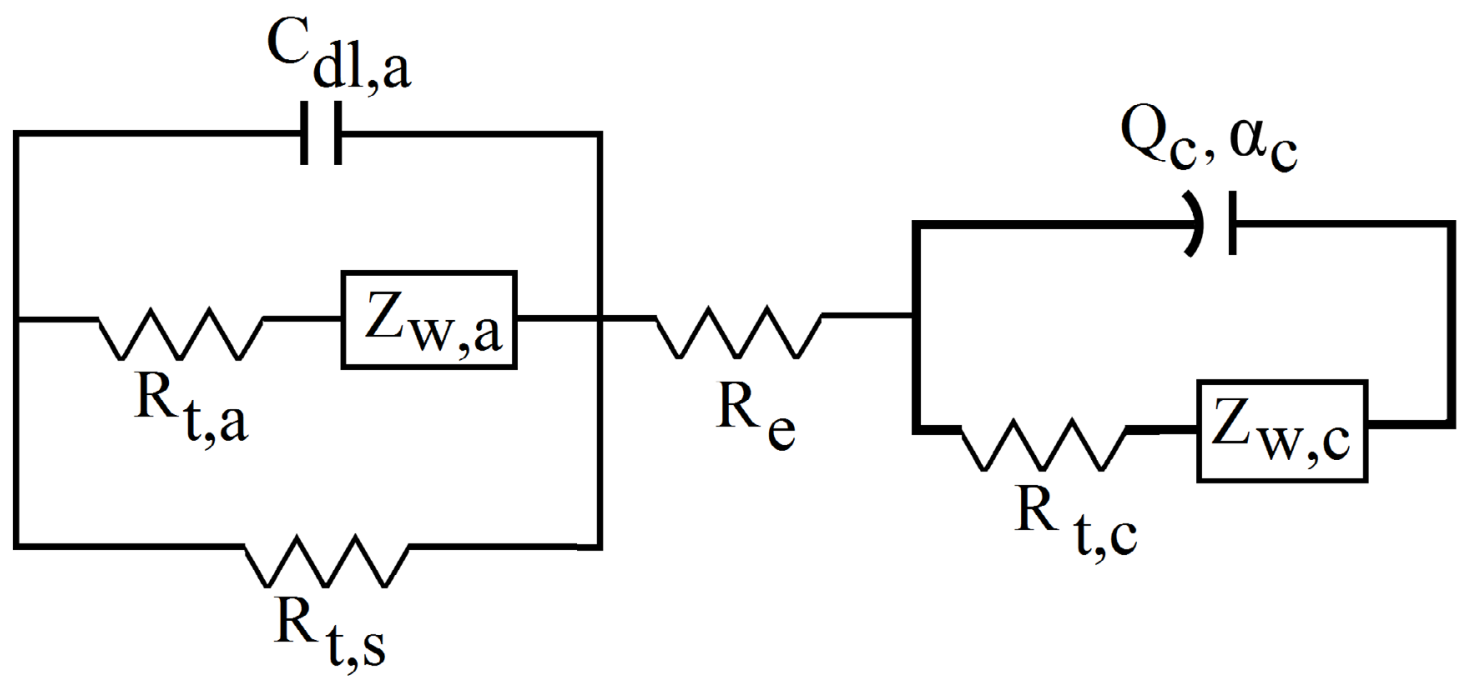

Figure 1. Equivalent circuit representation of the mathematical model used for the 2032 LIB.

electric field. The charging process was executed by the constant-current and constant-potential procedure. The 2032 button cells were charged from $3.20 \mathrm{~V}$ to the different SOCs by applying different charging currents. When the SOC reached the specified potential (35\% SOC, $70 \%$ SOC and 100\% SOC), the charging current (30 mA, $15 \mathrm{~mA}$ and $5 \mathrm{~mA}$ ) was allowed to decrease to $1 \mathrm{~mA}$ for a specific drop-time (30 min, $20 \mathrm{~min}$ and $10 \mathrm{~min}$ ). The impedance measurements at open-circuit were performed over a range of frequency between $100 \mathrm{kHz}$ and $0.01 \mathrm{~Hz}$ by applying $1 \mathrm{mV}$ potential perturbation. After each measurement, the cells were discharged at $0.5 \mathrm{C}$ down to potential of $3.20 \mathrm{~V}$, and subjected to the next Taguchi run. The set of experimental runs based on the Taguchi design was created by using Minitab ${ }^{\circledR} 17$ (Table 1). The Taguchi method is summarized in our previous study for detailed information [10]. Impedance data for each measurement was obtained through at least three replicated runs to ensure that the results were both consistent and reproducible. All of the impedance data gathered was analyzed by using Gamry Echem Analyst software.

A quantitative analysis of the fit of an equivalent circuit model to the impedance data was performed to characterize the impedance spectra. The equivalent circuit model developed by Erol and Orazem was used in this study (Figure 1) [11]. The equivalent circuit model contains an electrolyte resistance $R_{e^{\prime}}$ a charge transfer resistance for anode $R_{t, a^{\prime}}$ a double layer capacitance for anode $C_{d, a^{\prime}}$ the diffusion impedance for anode $Z_{w, a^{\prime}}$, the charge transfer resistance for solid electrolyte interp- hase $R_{t, s^{\prime}}$ the constant phase element for cathode CPE $\left(Q_{c}\right.$ and $\left.\alpha_{c}\right)$, the charge transfer resistance for cathode $R t, c$ and the diffusion impedance for cathode $Z_{w, c}$. A full description of the mathematical model is provided in Ref. [11] and will therefore not be duplicated here.

\section{RESULTS and DISCUSSION}

The impedance response of the $2032 \mathrm{Li}$-ion coin cells is presented as functions of SOC, charge current, and current drop time. Then, the equivalent circuit model fitted to the EIS data. Finally, the influential factors were determined through the Taguchi design.

\section{Analysis of impedance response}

The impedance response of 2032 coin cells is presented in Nyquist format (Figure 2). Three regions can be identified in the Nyquist plots. The Nyquist plots consist of two capacitive loops in the high and medium frequency regions [12]. A straight line at low frequencies is also seen in the representation of the impedance data [1]. The semi-circle at the higher frequencies represented the electrochemical phenomena at the anode side of the cell. The high frequency semi-circles in the Nyquist plots were observed not to change so much through the entire conditions. The high frequency semi-circle is generally ascribed to the impedance associated with the behavior of Li-ions through the SEI layer on anode [11]. The magnitude of the semi-circles representing the impedance through the SEI layer showed that the movement of the $\mathrm{Li}$-ions exhibited same behavior over the all runs. On the other hand, the impedance response at medium frequencies is not an exact semi-circle. Thus, 


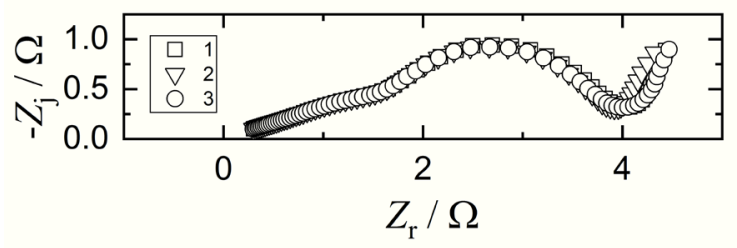

(a)

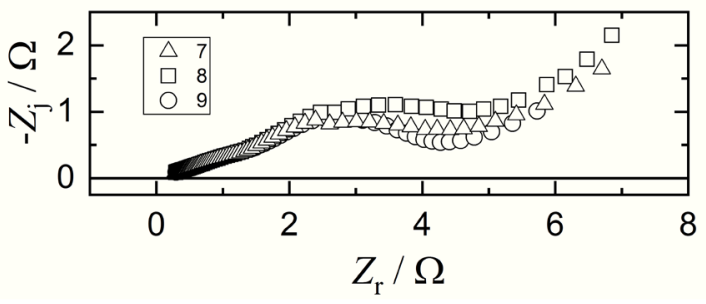

(c)

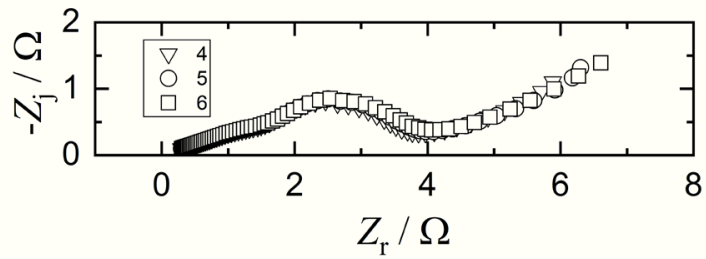

(b)

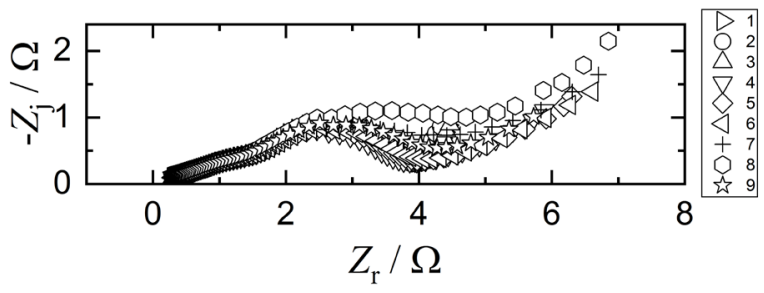

(d)

Figure 2. Impedance response in Nyquist format for a 2032 coin cell: a) as obtained from the runs 1-3; b) as obtained from the runs 4-6; c) as obtained from the runs 7-9; d) as obtained from all the runs in the L9 orthogonal array.

the loop in the medium frequency region of the Nyquist plots can be identified as a depressed semi-circle. The depressed semi-arc reflected the electrochemical reactions and other side reactions occurring at the cathode side of the battery [13]. The depressed semi-circle can be ascribed to the high charge transfer resistance associated with desolvation/solvation of Li-ions, and Li-ion intercalation/deintercalation into/from the cathode [14, 15]. The medium frequency representation of the impedance data showed that the size of the depressed semi-circle increased with the increasing SOC. The higher semi-arc at medium frequencies indicated that the Liion transportation over the cathode was difficult. The differences in the size and shape of the impedance response at medium frequencies showed that the applied conditions changed the charge transfer resistance for the cathode. Additionally, the impedance response of the $2032 \mathrm{Li}$-ion battery cells resemble the one resulted for lithium/graphite 2032 cell by Erol and Orazem [11]. The line in the low-frequency region corresponds to the behavior of lithium ions to diffuse from electrolyte to the electrode or vice versa [13]. The 2032 cells at the different conditions led to changes in the slope of the straight line in the Nyquist plot captured by the EIS measurements. The differences in the slope of straight line implied that the diffusion of Li-ions was influenced by the applied operation parameters.

\section{Regression of battery dynamics}

The mathematical representation of the equivalent circuit model (Figure 1) was used to fit the model to the impedance data. The resulting mathematical model can be presented as

$\mathrm{Z}=\mathrm{Z}_{\mathrm{a} \| \mathrm{s}}+\mathrm{R}_{\mathrm{e}}+\mathrm{Z}$

The impedance at negative electrode Zal|s in Equation 1 , given as

\begin{tabular}{|l|l|l|}
\hline$Z_{a|| s}(\omega)=\left(\left(R_{t, a}+Z_{w, a}\right) R_{t, s}\right) /\left(R_{t, a}+Z_{w, a}+j \omega(\right.$ & (2) \\
$\left.\left.R_{t, a}+Z_{w, a}\right) R_{t, s} C_{d \| l \mid s}\right)$
\end{tabular}

The cathode impedance $Z c$ in Equation 1 can be expressed as

$Z_{\mathrm{c}}=\left(\mathrm{R}_{\mathrm{t}, \mathrm{c}}+\mathrm{Z}_{\mathrm{w}, \mathrm{c}}\right) /\left(1+\mathrm{j} \omega^{\alpha c}\left(\mathrm{R}_{\mathrm{t}, \mathrm{c}}+\mathrm{Z}_{\mathrm{w}, \mathrm{c}}\right) \mathrm{Q}_{\mathrm{c}}\right)$

$Z \mathrm{~W}, \mathrm{c}$ is the Warburg impedance and can be defined as

$\mathrm{Z}_{\mathrm{w}, \mathrm{c}}=\mathrm{A}_{\mathrm{w}, \mathrm{c}} /(\mathrm{j} \omega)^{0.5}$

where Aw,c is coefficient of Warburg impedance.

The regressed model parameters are listed with confidence intervals (Table 2). The resulting values of battery dynamics showed that the applied factors (SOC, charge current and current-drop time) influenced the dynamic behavior of the cells. The following results will focus on the four resistors $R_{e^{\prime}} R_{t, s^{\prime}} R_{t, a}$, and $R_{t, c}$ assigned in the equivalent circuit model. These four resistors are ge- 
Table 2. Comparison of regression results with confidence intervals for model parameters.

\begin{tabular}{|c|c|c|c|c|c|c|c|c|c|}
\hline Run & $\begin{array}{c}\mathrm{R}_{\mathrm{e}} \\
\Omega \mathrm{cm}^{2}\end{array}$ & $\begin{array}{c}\mathrm{R}_{\mathrm{t}, \mathrm{s}} \\
\Omega \mathrm{cm}^{2}\end{array}$ & $\begin{array}{c}\mathrm{R}_{\mathrm{t}, \mathrm{a}} \\
\Omega \mathrm{cm}^{2}\end{array}$ & $\begin{array}{c}Z_{w, a} \\
\Omega \mathrm{cm}^{2} \mathrm{~s}^{-0.5}\end{array}$ & $\begin{array}{c}\mathrm{C}_{\mathrm{dl}, \mathrm{a}} \\
\mu \mathrm{F} \mathrm{Cm}^{-2}\end{array}$ & $\begin{array}{c}\mathrm{Q}_{\mathrm{c}} \\
\mathrm{F} \mathrm{cm}^{-2} \mathrm{~s}^{\alpha c-1}\end{array}$ & $\alpha_{c}$ & $\begin{array}{c}\mathrm{R}_{\mathrm{t}, \mathrm{c}} \\
\Omega \mathrm{cm}^{2}\end{array}$ & $\begin{array}{c}Z_{w, c} \\
\Omega \mathrm{cm}^{2} \mathrm{~s}^{-0.5}\end{array}$ \\
\hline 1 & $0.2228 \pm 0.0211$ & $1.355 \pm 0.02646$ & $0.1618 \pm 0.0153$ & $14.19 \pm 0.777$ & $8.257 \pm 2.323$ & $0.0374 \pm 0.0027$ & $0.841 \pm 0.0304$ & $2.396 \pm 0.089$ & $3.891 \pm 0.328$ \\
\hline 2 & $0.2205 \pm 0.0210$ & $1.355 \pm 0.02629$ & $0.1623 \pm 0.0152$ & $14.3 \pm 0.778$ & $8.217 \pm 2.299$ & $0.03646 \pm 0.0026$ & $0.855 \pm 0.0306$ & $2.285 \pm 0.085$ & $4.063 \pm 0.342$ \\
\hline 3 & $0.2209 \pm 0.0201$ & $1.344 \pm 0.02577$ & $0.1643 \pm 0.0150$ & $14.41 \pm 0.776$ & $8.49 \pm 2.263$ & $0.03857 \pm 0.0027$ & $0.831 \pm 0.0306$ & $2.369 \pm 0.091$ & $3.727 \pm 0.304$ \\
\hline 4 & $0.2286 \pm 0.0181$ & $1.199 \pm 0.02427$ & $0.1623 \pm 0.0157$ & $14.79 \pm 0.850$ & $9.657 \pm 2.436$ & $0.05322 \pm 0.0051$ & $0.706 \pm 0.0469$ & $2.705 \pm 0.201$ & $2.632 \pm 0.417$ \\
\hline 5 & $0.2314 \pm 0.018$ & $1.203 \pm 0.02449$ & $0.1633 \pm 0.0160$ & $14.67 \pm 0.856$ & $9.717 \pm 2.435$ & $0.05360 \pm 0.0049$ & $0.694 \pm 0.0418$ & $2.871 \pm 0.192$ & $2.639 \pm 0.433$ \\
\hline 6 & $0.2235 \pm 0.0224$ & $1.148 \pm 0.02678$ & $0.1488 \pm 0.0167$ & $13.69 \pm 0.919$ & $8.489 \pm 2.785$ & $0.05279 \pm 0.0045$ & $0.677 \pm 0.0371$ & $2.970 \pm 0.175$ & $1.370 \pm 0.0677$ \\
\hline 7 & $0.2322 \pm 0.0164$ & $0.8522 \pm 0.02255$ & $0.1277 \pm 0.0164$ & $18.17 \pm 1.398$ & $13.03 \pm 3.892$ & $0.09259 \pm 0.0081$ & $0.536 \pm 0.0295$ & $5.296 \pm 0.486$ & $1.023 \pm 0.0559$ \\
\hline 8 & $0.2367 \pm 0.018$ & $0.982 \pm 0.02399$ & $0.1341 \pm 0.0173$ & $15.93 \pm 0.0011$ & $11.52 \pm 0.0035$ & $0.07472 \pm 0.0078$ & $0.589 \pm 0.0404$ & $5.159 \pm 0.569$ & $1.280 \pm 0.346$ \\
\hline 9 & $0.2303 \pm 0.0191$ & $1.006 \pm 0.02457$ & $0.1444 \pm 0.0168$ & $15.36 \pm 0.0010$ & $10.3 \pm 3.085$ & $0.06322 \pm 0.0059$ & $0.607 \pm 0.0345$ & $3.839 \pm 0.276$ & $2.378 \pm 0.636$ \\
\hline
\end{tabular}

nerally identified as battery dynamics. The electrolyte resistance slightly increased with increasing SOC. The electrolyte resistance at $100 \%$ SOC was higher than that at $35 \%$ SOC. The increase in the electrolyte resistance could be attributed to the concentration of Li-ions in the electrolyte. The charge transfer resistance for the SEl formation was higher than the charge transfer resistance for the anode intercalation. The higher charge transfer resistance for the SEI formation reaction indicated that the impedance response at the anode side of the cells was largely due to the SEl layer formed on the anode. It can be seen the cathodic charge transfer resistance value as an increasing function of SOC for all charge currents; however, the increasing trend became more evident at $100 \%$ SOC. An additional layer on the cathode can be formed during the cell operations. The formed cathodic layer is generally attributed to the side-reaction products [9]. Furthermore, the side-reactions can consume the Li-ions in the cells. Thus, the increase in the charge transfer resistance for the cathode can be ascribed to both the consumption of Li-ions and the formation of the cathodic layer.

\section{Taguchi design of battery dynamics}

The Taguchi design provides appropriate data to get an efficient statistical analysis. The statistical approach provides to enable the evaluation of the influence of all levels of factors at the same time. The determination of the objective function is the first step of the Taguchi design. In this study, the objective function was minimization of battery dynamics of the 2032 coin cells. Battery dynamics were $R_{e^{\prime}}, R_{t, s^{\prime}} R_{t, a}$ and $R_{t, c}$ representing the electrolyte resistance, the resistance for the SEI formation reaction, the resistance for the anodic charge transfer reaction and the cathodic charge transfer resistance, respectively. It is important to note that the resistances representing battery dynamics of the 2032 button cells should be as low as possible. Therefore, smaller-is-better quality characteristic was selected as signal-to-noise ratio $(\mathrm{S} / \mathrm{N})$ to determine the significance of the response variables (battery dynamics). The $\mathrm{S} / \mathrm{N}$ ratios for all the levels of the factors $(\mathrm{SOC}$, charge current and drop time) were calculated and represented in response table (Table 3). The applied L9 orthogonal array enabled to analyze the entire parameter space (Table 1).

The effect of SOC on battery dynamics was the highest based on the results of the response table. Rank 1 indicated the higher significance level of the SOC for all the resistances. In other words, small changes in the SOC substantially influence battery dynamics. It is important to emphasize that the SOC with the largest delta value was given rank 1 for all the resistances. On the other hand, rank 2 for the $\mathrm{R}_{e}$ indicated that the applied charge current was the second influential factor on the electrolyte resistance. The influence of the time allowed for the current drop on the electrolyte resistance was lower than the effects of SOC and charge current. The effect of the drop time on the $R_{e}$ parameter was indicated by the difference between the highest and lowest $\mathrm{S} / \mathrm{N}$ ratios of the drop time. The lowest difference in the $\mathrm{S} / \mathrm{N}$ ratios of the drop time induced Rank 3 for the drop time. For battery dynamics except for the electrolyte resistance, the drop time with the second largest delta value was given rank 2 . Thus, the charge current was given Rank 3. The response table also showed that the influence of drop time on the charge transfer resistance for the SEl formation reaction was higher than that of the 
Table 3. Response table of battery dynamics for signal-to-noise ratios $(\mathrm{S} / \mathrm{N})$ - smaller is better.

\begin{tabular}{|c|c|c|c|c|c|c|c|}
\hline \multicolumn{4}{|c|}{$R_{e}$} & \multicolumn{4}{|c|}{$R_{t, s}$} \\
\hline Level & SOC & $\begin{array}{l}\text { charge } \\
\text { current }\end{array}$ & drop time & Level & SOC & $\begin{array}{l}\text { charge } \\
\text { current }\end{array}$ & drop time \\
\hline 1 & 13.1 & 12.96 & 12.84 & 1 & -2.6152 & -1.2729 & -0.928 \\
\hline 2 & 12.85 & 12.79 & 12.9 & 2 & -1.4602 & -1.3612 & -1.4224 \\
\hline 3 & 12.65 & 12.85 & 12.86 & 3 & 0.4992 & -0.942 & -1.2257 \\
\hline Delta & 0.45 & 0.17 & 0.06 & Delta & 3.1144 & 0.4192 & 0.4943 \\
\hline Rank & 1 & 2 & 3 & Rank & 1 & 3 & 2 \\
\hline \multicolumn{4}{|c|}{$R_{t, a}$} & \multicolumn{4}{|c|}{$R_{t, c}$} \\
\hline Level & SOC & $\begin{array}{l}\text { charge } \\
\text { current }\end{array}$ & drop time & Level & SOC & $\begin{array}{l}\text { charge } \\
\text { current }\end{array}$ & drop time \\
\hline 1 & 15.77 & 16.35 & 16.43 & 1 & -7.42 & -9.544 & -10.377 \\
\hline 2 & 16.03 & 16.33 & 16.13 & 2 & -9.086 & -10.197 & -9.168 \\
\hline 3 & 17.38 & 16.5 & 16.61 & 3 & -13.472 & -10.237 & -10.432 \\
\hline Delta & 1.61 & 0.17 & 0.47 & Delta & 6.052 & 0.694 & 1.264 \\
\hline Rank & 1 & 3 & 2 & Rank & 1 & 3 & 2 \\
\hline
\end{tabular}

charge current. This order between the charge current and drop time was in force for both the anodic charge transfer resistance and cathodic charge transfer resistance.

To perform analysis of variance (ANOVA), a significance level of 0.05 was selected from the typical values for alpha. The significance level of 0.05 indicates a $5 \%$ risk of concluding that the coefficient is not 0 when it is. A calculated probability ( $\mathrm{P}$-value) was calculated to indicate the evidence against the null hypothesis. The ANO$\checkmark A$ results (Table 4) showed that no significant effect of both the SOC, charge current, and drop time on the electrolyte resistance was observed since the $\mathrm{P}$-values for the Re were higher than 0.05. The P-values of the SOC smaller than 0.05 indicated that there was a statistically significant association between the charge level and both $R_{t, s^{\prime}}$ and $R_{t, c}$. The results statistically indicated that there was no relationship between the charge current and battery dynamics was visible. In addition, the P-value bigger than 0.05 showed that the influence of drop time on battery dynamics was not statistically significant.

\section{Conclusion}

The impact of state-of-charge, charging current and drop time on battery dynamics of the commercial 2032 LiNiMnCoO $/ \mathrm{C}$ battery was assessed by using the electrochemical impedance spectroscopy combined with the Taguchi design. The state-of-charge was a crucial factor greatly affecting battery dynamics. The statisti- cally significant association was observed between the state-of-charge and the resistance for the solid electrolyte interphase formation reaction. In addition, the state-of-charge had a profound influence on the cathodic charge transfer resistance. The electrochemical impedance spectroscopy combined with the Taguchi design opened the door for a more detailed understanding of a commercial $\mathrm{LiNiMnCoO} / \mathrm{C}$ coin cell that enables a robust design of lithium-ion batteries in real life.

\section{Acknowledgments}

This study was supported by Eskisehir Osmangazi University Scientific Research Foundation (grant number 2017-1911). 
Table 4. Response table of battery dynamics for signal-to-noise ratios $(\mathrm{S} / \mathrm{N})$ - smaller is better.

\begin{tabular}{|c|c|c|c|c|c|c|}
\hline \multicolumn{7}{|c|}{$\mathrm{R}_{\mathrm{e}}$} \\
\hline Source & DF & Seq SS & Adj SS & Adj MS & $F$ & $P$ \\
\hline SOC & 2 & 0.0002049 & 0.0002049 & 0.0001024 & 10.73 & 0.085 \\
\hline Charge current & 2 & 0.000033 & 0.000033 & 0.0000165 & 1.73 & 0.366 \\
\hline Drop time & 2 & 0.0000046 & 0.0000046 & 0.0000023 & 0.24 & 0.806 \\
\hline Error & 2 & 0.0000191 & 0.0000191 & 0.0000095 & & \\
\hline Total & 8 & 0.0002616 & & & & \\
\hline \multicolumn{7}{|c|}{$R_{t, a}$} \\
\hline Source & DF & Seq SS & Adj SS & Adj MS & $\mathrm{F}$ & $P$ \\
\hline SOC & 2 & 0.0012893 & 0.0012893 & 0.0006447 & 7.74 & 0.114 \\
\hline Charge & 2 & 0.0000111 & 0.0000111 & 0.0000055 & 0.07 & 0.938 \\
\hline current & 2 & 0.0000989 & 0.0000989 & 0.0000495 & 0.59 & 0.627 \\
\hline Error & 2 & 0.0001666 & 0.0001666 & 0.0000833 & & \\
\hline Total & 8 & 0.001566 & & & & \\
\hline \multicolumn{7}{|c|}{$R_{t, s}$} \\
\hline Source & DF & Seq SS & Adj SS & Adj MS & $\mathrm{F}$ & $\mathrm{P}$ \\
\hline SOC & 2 & 0.248033 & 0.248033 & 0.124016 & 30.22 & 0.032 \\
\hline Charge & 2 & 0.00311 & 0.00311 & 0.001555 & 0.38 & 0.725 \\
\hline current & 2 & 0.004315 & 0.004315 & 0.002158 & 0.53 & 0.655 \\
\hline Error & 2 & 0.008208 & 0.008208 & 0.004104 & & \\
\hline Total & 8 & 0.263666 & & & & \\
\hline \multicolumn{7}{|c|}{$R_{t, c}$} \\
\hline Source & DF & Seq SS & Adj SS & Adj MS & $\mathrm{F}$ & $P$ \\
\hline $\mathrm{SOC}$ & 2 & 9.7503 & 9.7503 & 4.8752 & 25.37 & 0.038 \\
\hline Charge & 2 & 0.3095 & 0.3095 & 0.1547 & 0.81 & 0.554 \\
\hline current & 2 & 0.6434 & 0.6434 & 0.3217 & 1.67 & 0.374 \\
\hline Error & 2 & 0.3844 & 0.3844 & 0.1922 & & \\
\hline Total & 8 & 11.0876 & & & & \\
\hline
\end{tabular}

\section{References}

1. U. Moralı, S. Erol, 18650 lityum-iyon ve 6HR61 nikelmetal hidrit tekrar şarj edilebilir pillerinin elektrokimyasal empedans analizi, J. Fac. Eng. Archit. Gaz., 35 (2020) 297-310.

2. H. Wang, S. Frisco, E. Gottlieb, R. Yuan, J.F. Whitacre, Capacity degradation in commercial Li-ion cells: The effects of charge protocol and temperature, J. Power Sources, 426 (2019) 67-73.

3. R. Gopalakrishnan, Y. Li, J. Smekens, A. Barhoum, G. Van Assche, N. Omar, J. Van Mierlo, Electrochemical impedance spectroscopy characterization and parameterization of lithium nickel manganese cobalt oxide pouch cells: dependency analysis of temperature and state of charge, Ionics, 25 (2018) 111-123.
4. T. Amietszajew, E. McTurk, J. Fleming, R. Bhagat, Understanding the limits of rapid charging using instrumented commercial 18650 high-energy Li-ion cells, Electrochim. Acta, 263 (2018) 346-352.

5. S. Erol, M.E. Orazem, R.P. Muller, Influence of overcharge and over-discharge on the impedance response of LiCoO2 $\mid \mathrm{C}$ batteries, J. Power Sources, 270 (2014) 92-100.

6. S. Buteau, D. Dahn, J. Dahn, Explicit conversion between different equivalent circuit models for electrochemical impedance analysis of lithium-ion cells, J. Electrochem. Soc., 165 (2018) A228-A234.

7. C. Yu, S. Ganapathy, E. Eck, H. Wang, S. Basak, Z. Li, M. Wagemaker, Accessing the bottleneck in all-solid state batteries, lithium-ion transport over the solid-electrolyteelectrode interface, Nat. Commun., 8 (2017) 1086. 
8. J. Xu, X. Wang, N. Yuan, J. Ding, S. Qin, J.M. Razal, X. Wang, S. Ge, Y. Gogotsi, Extending the low temperature operational limit of Li-ion battery to- $80^{\circ} \mathrm{C}$, Energy Stor. Mater., 23 (2019) 383-389.

9. A. Schmidt, A. Smith, H. Ehrenberg, Power capability and cyclic aging of commercial, high power lithium ion battery cells with respect to different cell designs, J. Power Sources, 425 (2019) 27-38

10. U. Moralı, H. Demiral, S. Şensöz, Optimization of activated carbon production from sunflower seed extracted meal: Taguchi design of experiment approach and analysis of variance, J. Clean. Prod., 189 (2018) 602-611.

11. S. Erol, M.E. Orazem, The influence of anomalous diffusion on the impedance response of $\mathrm{LiCoO}_{2} \mid \mathrm{C}$ batteries, J. Power Sources, 293 (2015) 57-64.
12. A. Barai, K. Uddin, M. Dubarry, L. Somerville, A. McGordon, P. Jennings, I. Bloom, A comparison of methodologies for the non-invasive characterisation of commercial Li-ion cells, Prog. Energ. Combust., 72 (2019) 1-31.

13. D. Juarez-Robles, C.F. Chen, Y. Barsukov, P.P. Mukherjee, Impedance evolution characteristics in lithium-ion batteries, J. Electrochem. Soc., 16 (2017) A837-A847.

14. R. Tatara, P. Karayaylali, Y. Yu, Y. Zhang, L. Giordano, F. Maglia, R. Jung, J.P. Schmidt, I. Lund, Y. Shao-Horn, The effect of electrode-electrolyte interface on the electrochemical impedance spectra for positive electrode in Li-ion battery, J. Electrochem. Soc., 166 (2019) A5090-A5098.

15. A. Yürüm, Sunflower Stalk Based Activated Carbon for Supercapacitors, Hacettepe J. Biol. Chem., 47 (2019) 235247. 